\title{
Pasture renovation after winter pugging damage
}

\author{
R.J JOHNSON', D.A. MCCALLUM' and N.A. THOMSON ${ }^{2}$ \\ ${ }^{\prime}$ Dairying Research Corporation, Taranaki Agricultural Research Station, PO Box 711. Hawera. \\ 2 Dairying Research Corporation, PB 3123, Hamilton'
}

\begin{abstract}
In New Zealand where cows are grazed on pasture throughout winter, severe pugging damage can occur particularly during wet and stormy weather. On a severely pugged area, seasonal and annual dry matter (DM) production of 3 reseeding treatments (broadcast ryegrass seed followed by rolling or harrowing, drilled ryegrass seed followed by harrowing) and three non-seeded treatments (rolling, harrowing and an untreated control) were compared over 2 years. Average annual DM production of the three reseeding treatments was higher $(\mathrm{P}<0.05)$ than the unseeded treatments. Rolling and harrowing without reseeding had no effect on DM production or pasture composition. The three reseeding treatments had higher ryegrass percentage $(P<0.01)$ and lower $(P<0.01)$ other grasses percentage than the treatments with no ryegrass seed included. These differences in pasture composition were greatest in each spring 15 and 27 months after treatments were applied. The differences in production of the reseeded treatments persisted over the 2-year study period, showing that "undersowing" had a long-term beneficial effect on pugged pastures.
\end{abstract}

Keywords: harrowing, pasture production, pasture renovation, pugging, reseeding, rolling

\section{Introduction}

Taranaki soils are free draining and the climate is considered to be ideal for dairying; rainfall ranges from $1100 \mathrm{~mm} / \mathrm{year}$ to $2800 \mathrm{~mm} / \mathrm{year}$ and is evenly distributed throughout the year (NZ Meteorological Station Normanby E94.526). However, winter pugging damage does occur. Brown \& Evans (1973) reported a reduction in pasture growth after treading treatments on Egmont brown loam soil, and Kairanga silt loam, a heavy clay soil unable to withstand winter treading. In all of Edmond's work $(1958,1962,1963)$ the effect of treading only on pasture production and composition was examined as pugging was avoided in all these studies.

Losses of pasture growth resulting from stock treading is due partly to physical damage to plants, causing death, and compaction, causing anaerobic soil conditions (Gradwell 1965; Climo \& Richardson 1984).
Good farm management aims at minimising pugging damage by removing stock from pasture or giving stock more area during excessively wet periods. When severe pasture pugging has occurred, rolling or harrowing has been practised by many Taranaki dairy farmers to even the surface, improve water run off and replace uprooted plants (Thomson pers. comm.). Reseeding of heavily pugged areas through broadcasting seed and harrowing has also been used to a limited extent. Claims to the success of the various methods have been made, but no objective information was available to assess the relative benefits. This study therefore investigated the possible benefits to rolling or harrowing on pugged areas accompanied by reseeding.

\section{Materials and methods}

The most common method of wintering dry cows on pasture in New Zealand is by block grazing on a 100- to 120-day rotation. Block grazing involves having the herd of dry cows confined daily to a square area of pasture at a density of 250-500 cows/ha/day. Each day the cows are shifted to a new area of pasture. Late in July 1990 soils at the Taranaki Agricultural Research Station (Egmont brown loam) were at field capacity. In a paddock where dry dairy cows were being block grazed severe pasture pugging damage occurred after a 24-hour period when $13.2 \mathrm{~mm}$ of rain fell on already saturated soils. The cows' hooves had broken through the soil surface by approximately $4-8 \mathrm{~cm}$ which resulted in the displacement of a large proportion of plants. Vegetation had been buried and root material exposed and damaged by the impact of hooves. This situation was seen as an ideal opportunity to investigate the effects of pasture renovation on a pugged area.

Six weeks later on this severely pugged area 6 treatments were established and compared over 2 years: 1) no form of repair (control), 2) harrowing, 3) rolling, 4) broadcasting ryegrass seed followed by harrowing or 5) rolling, and 6) drilling ryegrass seed followed by harrowing. Non-pugged pasture was not available for comparison. The trial area was first grazed hard (4-5 $\mathrm{cm})$ with dairy cows and treatments were applied immediately after grazing.

A randomised block design with 4 replicates was used, with plot size of $2.6 \mathrm{~m}$ x $6 \mathrm{~m}$ for all treatments except the drilling ryegrass seed followed by harrowing which had a plot size of $2.25 \mathrm{~m} \mathrm{x} 6 \mathrm{~m}$. All ryegrass 
treatments were sown at $15 \mathrm{~kg} / \mathrm{ha}$ of Yatsyn-1 perennial ryegrass by a Duncan triple disk drill (drill treatment) or by hand (broadcast treatment). Chain harrows or a Cambridge roller were used behind a tractor for the harrow and roll treatments, respectively. The first grazing was 23 days after application of treatments and then the experimental area was fitted into the normal intensive dairy management system of rotational grazing (30-day rotation during lactation and 120-day round in the winter) for the duration of the experiment. The soil fertility of the site was considered to be adequate for pasture growth (Quick Test $\mathrm{pH}=6.1, \mathrm{Ca}=5, \mathrm{~K}=11, \mathrm{P}=16$ $\mathrm{Mg}=41, \mathrm{~S}=23$ ) and was maintained through the experimental period with the application of $12.5 \mathrm{~kg} \mathrm{P} /$ ha and as triple super and $68 \mathrm{~kg} \mathrm{~K} / \mathrm{ha}$ applied as potassic sulphate.

Ryegrass plant density was measured 6 weeks after sowing by counting new ryegrass plants in 12,20 x 20 $\mathrm{cm}^{2}$ quadrats/plot. Herbage mass before and after grazing was assessed using the Mozaic Systems (Mark III) pasture probe to assess pasture growth for 2 years. The mean of 30 meter readings/plot was converted to herbage mass using formulae for each season as defined by L'Hullier \& Thomson 1988. Pasture samples, cut to grazing height using hand shears, were taken seasonally and hand dissected into ryegrass, other grasses, clover, weeds and dead matter.

\section{R esults}

\section{Ryegrass density}

Perennial ryegrass plant density was higher for broadcast reseeding followed by either harrowing or rolling, than the control treatment $(\mathrm{P}<0.05$, Table 1$)$. Drilling ryegrass seed followed by harrowing increased $(P<0.05)$ plant density compared with the control or harrowing treatments, but not rolling alone (Table 1).

\section{Botanical composition}

No differences between treatments were recorded for clover, weed and dead matter content of pasture. However, throughout the trial the content of ryegrass and other grasses differed significantly between treatments (Table 2). The major other grass species in order of dominance were: cocksfoot (Dactylis glomerata), Poa annua, Poa pratensis and couch (Agropyron repens). No consistent effect of treatments on the order of dominance of the other grass species was apparent.

Treatment effects on pasture composition were most marked in spring each year, 15 and 27 months after treatments were applied. In general, reseeding pugged areas increased ryegrass content $(\mathrm{P}<0.01)$ and decreased the content of other grasses $(\mathbf{P}<0.01)$. Averaged over 2
Table 1 Effect of renovation treatments on ryegrass plant counts 6 weeks after reseeding (plants $/ \mathrm{m}^{2}$ )

\begin{tabular}{lc}
\hline Treatment & $\begin{array}{c}\text { Ryegrass Density } \\
\text { No.s/m }\end{array}$ \\
\hline Control & 138 \\
Harrow & 134 \\
Roll & 188 \\
Drill + Harrow & 230 \\
Broadcast + Harrow & 313 \\
Broadcast + Roll & 304 \\
Significance &. \\
LSD 0.05 & 89 \\
\hline
\end{tabular}

years, ryegrass content increased from $45 \%$ to $62 \%$ and the other grass content decreased from 39\% to $24 \%$ with reseeding. No consistent effect of rolling or harrowing and drilling or broadcasting seed was apparent.

\section{Dry matter production}

Average annual DM production of the three reseeding treatments was higher than without reseeding (Table 3). Broadcasting ryegrass seed followed by harrowing or roliing increased $(\mathrm{P}<0.05)$ the annual DM production compared with the three unsown treatments. Drilling ryegrass seed followed by harrowing produced more DM $(\mathrm{P}<0.05)$ than the control. The main yield advantage from reseeding occurred during spring when average DM production was $16 \%$ greater than that of the unsown treatments. Greater DM yield on the reseeded treatments was associated with increased ryegrass yield. In the second year, the difference in ryegrass yield between unseeded and reseeded treatments was greater than in the first.

\section{Discussion}

The effects of stock treading on pasture productivity and pasture composition, and the effects soil type have on the pasture response to stock treading, have been well documented by Edmond (1958, 1962, 1963) and Brown \& Evans (1973). Edmond reported that treading damage, especially on wet soil, reduced pasture yield. No research has been conducted on repairing areas severely damaged by stock treading. In this trial average annual DM production of the three reseeding treatments was higher $(\mathrm{P}<0.05)$ than no form of repair. Harrowing or rolling without reseeding had no effect on pasture production or pasture composition. Thorn et al. (1987) reported that reseeding in existing pasture is effective only when established plants are weak or absent and there are significant areas of bare ground. Pastures affected by pugging damage have fewer grass tillers 
Table 2 Effect of pugged renovation on pasture composition

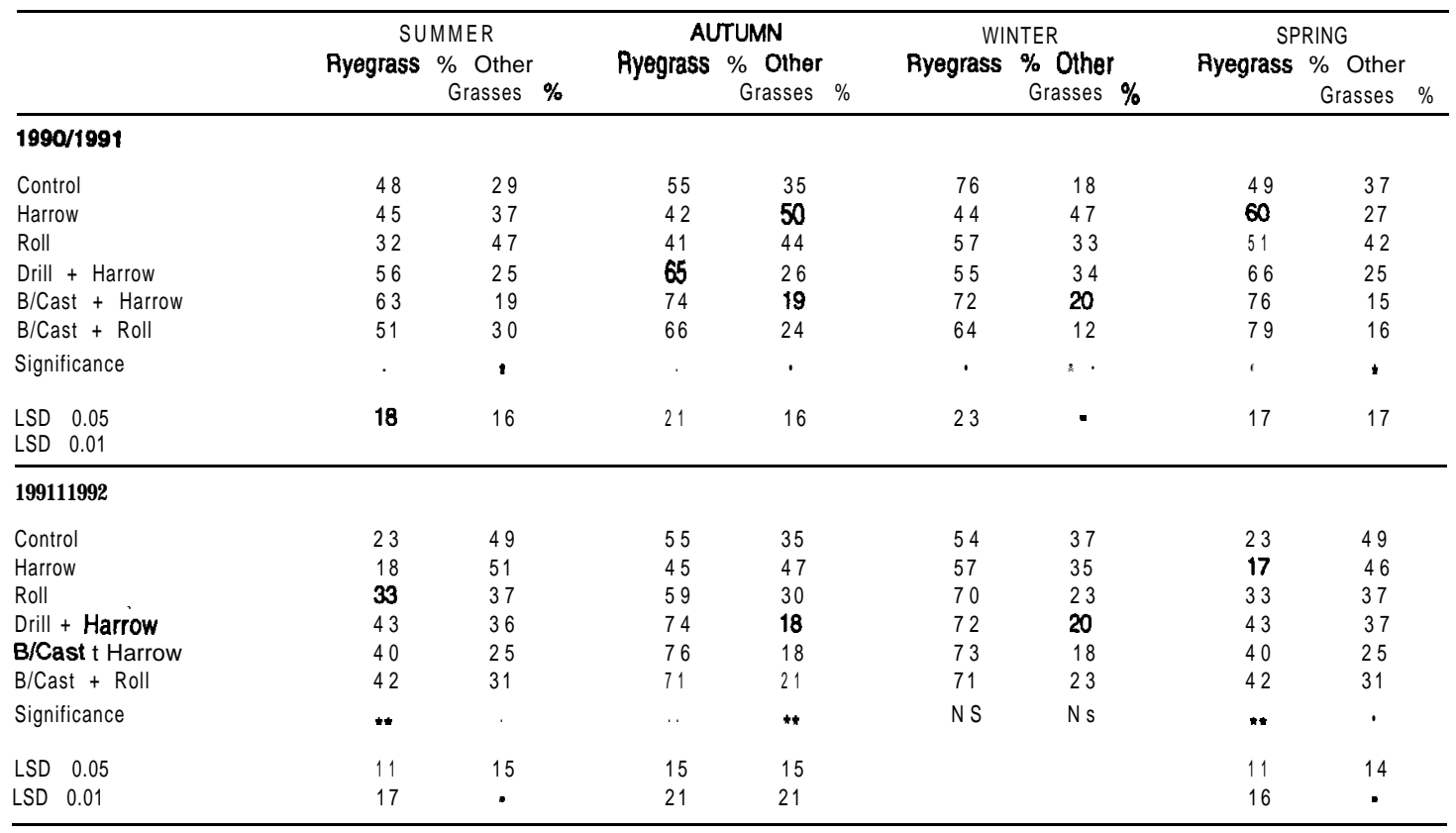

Table 3 Effect of pugging renovation treatments on pasture and ryegrass yield (t DM/ha)

\begin{tabular}{|c|c|c|c|c|c|c|c|c|c|c|}
\hline & \multicolumn{2}{|c|}{ SUMMER } & \multicolumn{2}{|c|}{ AUTUMN } & \multicolumn{2}{|c|}{ WINTER } & \multicolumn{2}{|c|}{ SPRING } & \multicolumn{2}{|c|}{ TOTAL } \\
\hline & Total & Ryegrass & Total & Ryegrass & Total & Ryegrass & Total & Ryegrass & Total & Ryegrass \\
\hline \multicolumn{11}{|l|}{$1990 / 1991$} \\
\hline Control & 2.9 & 1.4 & 1.5 & 0.8 & 1.8 & 1.3 & 3.9 & 1.9 & 10.0 & 5.4 \\
\hline Harrow & 2.6 & 1.2 & 1.6 & 0.7 & 1.8 & 0.8 & 4.0 & 2.4 & 10.0 & 5.1 \\
\hline & 2.7 & 0.9 & 1.6 & 0.6 & 1.8 & 1.1 & 4.2 & 2.2 & 10.3 & 4.9 \\
\hline Drill + Harrow & 3.0 & 1.7 & 1.9 & 1.2 & 2.1 & 1.1 & 4.7 & 3.1 & 11.7 & 7.1 \\
\hline B/Cast $t$ Harrow & 2.4 & 1.5 & 1.8 & 1.3 & 2.3 & 1.6 & 4.8 & 3.7 & 11.3 & 8.1 \\
\hline B/Cast + Roll & 2.5 & 1.2 & 1.7 & 1.2 & 1.9 & 1.6 & 4.8 & 3.8 & 10.9 & 7.9 \\
\hline Significance & 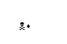 & - & $:$ & - & " & - & $"$ & 11 & · & " \\
\hline LSD $\quad 0.05$ & & 0.5 & & 0.4 & 0.3 & 0.6 & 0.6 & 0.8 & 1.2 & 1.4 \\
\hline LSD 0.01 & & & & & & & 0.8 & 1.1 & & 2.0 \\
\hline \multicolumn{11}{|l|}{$1991 / 92$} \\
\hline Control & 2.9 & 1.1 & 1.2 & 0.6 & 1.0 & 0.8 & 3.4 & 0.8 & 8.5 & 3.1 \\
\hline Harrow & 3.6 & 1.1 & 1.1 & 0.5 & 1.0 & & 3.4 & 0.6 & 8.9 & 4.1 \\
\hline Roll & 3.4 & 1.7 & 1.1 & 0.7 & 0.9 & 15 if & 3.3 & 1.1 & 8.9 & 2.7 \\
\hline Drill + Harrow & 3.7 & 2.1 & 1.3 & 0.9 & 1.0 & 0.7 & 3.7 & 1.6 & 9.7 & 5.3 \\
\hline B/Cast + Harrow & 3.9 & 2.3 & 1.3 & 1.0 & 1.2 & 0.9 & 3.7 & 1.5 & 10.1 & 5.7 \\
\hline B/Cast + Roll & 3.9 & 2.3 & 1.5 & 1.1 & 1.4 & 1.0 & 4.4 & 1.9 & 11.2 & 6.3 \\
\hline Significance & . & • $\bowtie$ & Ns & $*$ & $\cdot \square$ & " & . & .. & ' & $\omega$ \\
\hline LSD $\quad 0.05$ & & 0.6 & & 0.2 & 0.2 & 0.2 & 0.4 & 0.5 & 1.4 & 1.0 \\
\hline LSD 0.01 & & 0.9 & & 0.3 & 0.3 & 0.3 & 0.5 & 0.7 & 1.9 & 1.5 \\
\hline
\end{tabular}

than untrodden ground and therefore represent the ideal opportunity for successful reseeding. Thorn \& Barker (1992) stated for optimum seedling establishment after broadcasting it is necessary to cover the seed with loose soil or trash. In this trial, the harrowing or rolling achieved this and good seedling establishment resulted (Table 1).

The successful establishment of ryegrass resulted in greater ryegrass plant density (Table 1) and content (Table 2), and consequently increased DM production 
(Table 3) for 2 subsequent years. When these areas were not reseeded other less productive grass species appeared to successfully invade the bare areas.

\section{Conclusion}

Mechanical reseeding of severely pugged areas with an improved cultivar of ryegrass had a long-term (2 years) effect on ryegrass content and DM production. Areas not reseeded with ryegrass were invaded with less productive grasses: cocksfoot, poa species and couch. Attempts to repair pugged areas by either rolling or harrowing were ineffective.

\section{REFERENCES}

Brown, K.R.; Evans, P.S 1973. Animal treading. A review of the work of the late D.B. Edmond. New Zealand journal of experimental agriculture 1: 217. 26.

Climo, W.J.; Richardson, M.A. 1984. Factors affecting the susceptibility of 3 soils in the Manawatu to stock treading. New Zealand journal of agricultural research 27: 247-53.

Edmond, D.B. 1958. The influence of treading on pasture. A preliminary study. New Zealand journal of agricultural research 1: 3 19-28.
Edmond, D.B. 1962. Effects of treading pasture in summer under different soil moisture levels. New Zealand journal of agricultural research 5: 389. 95.

Edmond, D.B. 1963. Effect of treading perennial ryegrass (Lolium perenne L.) and white clover (Trifolium repens L.) pastures in winter and summer at two moisture levels. New Zealand Journal of Agricultural Research 6: 265-76.

Gradell, M.W. 1965. Soil physical conditions of winter and the growth of ryegrass plants. I. Effects of compaction and pugging. New Zealand journal of agricultural research 8: 238-69.

L'Hullier, P.J.; Thomson, N.A. 1988. Estimation of herbage mass in ryegrass/white clover dairy pastures. Proceedings of the New Zealand Grassland Association 49: 117-22.

Thorn, E.R.; Prestidge, R.A.; Barker, G.M. 1987. Pasture establishment on the dairy farm. Proceedings of the Ruakura Farmers Conference 39: X-52.

Thorn, E.R.; Barker, G.M. 1992. Techniques for pasture renovation or renewal pp. 16-24. In Pasture renovation manual, Pottinger, R.P.; Lane, P.M.S.; Wilkins, J.R. eds. New Zealand Pastoral Research Institute Ltd. 